\title{
Human placental growth hormone in normal and abnormal fetal growth (Review)
}

\author{
ALEXANDROS VELEGRAKIS $^{1}$, MARIA SFAKIOTAKI ${ }^{2}$ and STAVROS SIFAKIS ${ }^{3}$ \\ ${ }^{1}$ Department of Obstetrics and Gynecology, Venizelion General Hospital, Heraklion 71409; \\ Departments of ${ }^{2}$ Endocrinology and ${ }^{3}$ Obstetrics and Gynecology, University Hospital of Heraklion, Heraklion 71201 , Greece
}

Received February 2, 2017; Accepted May 31, 2017

DOI: $10.3892 /$ br.2017.930

\begin{abstract}
Human placental growth hormone (PGH), encoded by the growth hormone $(\mathrm{GH})$ variant gene on chromosome 17 , is expressed in the syncytiotrophoblast and extravillous cytotrophoblast layers of the human placenta. Its maternal serum levels increase throughout pregnancy, and gradually replaces the pulsatile secreted pituitary GH. PGH is also detectable in cord blood and in the amniotic fluid. This placental-origin hormone stimulates glyconeogenesis, lipolysis and anabolism in maternal organs, and influences fetal growth, placental development and maternal adaptation to pregnancy. The majority of these actions are performed indirectly by regulating maternal insulin-like growth factor-I levels, while the extravillous trophoblast involvement indicates a direct effect on placental development, as it stimulates trophoblast invasiveness and function via a potential combination of autocrine and paracrine mechanisms. The current review focuses on the role of PGH in fetal growth. In addition, the association of PGH alterations in maternal circulation and placental expression in pregnancy complications associated with abnormal fetal growth is briefly reviewed.
\end{abstract}

\section{Contents}

1. Introduction

2. Origin of $\mathrm{PGH}$

3. PGH in pregnancy and fetal growth

4. $\mathrm{PGH}$ in pathological pregnancy

5. $\mathrm{PGH}$ in oncogenesis and in gestational trophoblastic disease

6. Conclusion

Correspondence to: Dr Stavros Sifakis, Department of Obstetrics and Gynecology, University Hospital of Heraklion, Voutes, Heraklion 71201, Greece

E-mail: stavros.sifakis@yahoo.com

Key words: fetal growth, intrauterine growth restriction, placental growth hormone, preeclampsia, pregnancy

\section{Introduction}

Human placental growth hormone (PGH) is produced by the growth hormone $(\mathrm{GH})$ variant gene on chromosome 17 (1). PGH is expressed in the syncytiotrophoblast and extravillous cytotrophoblast (EVCT) layers of the human placenta. PGH is detectable in the fetal compartment, in cord blood and amniotic fluid (2). Its level increases in maternal circulation throughout pregnancy from gestational weeks 5 to 7 until term (3), and gradually after the fifteenth to twentieth week of pregnancy, replacing the pulsatile secreted pituitary $\mathrm{GH}(4)$.

PGH is considered as key in the regulation of maternal insulin-like growth factor-I (IGF-I) (5-7). Furthermore, PGH stimulates gluconeogenesis, lipolysis, and anabolism in maternal tissues and influences fetal growth, placental development (8) and maternal adaptation to pregnancy (9-11). The majority of these actions are exerted indirectly by regulating the maternal IGF-I expression levels $(3,6,12)$, while the extravillous trophoblast expression of PGH indicates a direct impact upon the physiological development of the placenta, as it stimulates trophoblast invasiveness and function via a potential combination of autocrine and paracrine mechanisms (13). The aim of the current review was to elucidate the role of PGH in fetal growth.

\section{Origin of PGH}

Human GHs are the products of five genes, members of the GH gene-family, located on the long arm of chromosome 17 (q22 to q24) (14); encoding pituitary GH (GH-N gene), $\mathrm{PGH}$ (GH-V gene), and three chorionic somatomammotropins/placental lactogens (hCS-A, hCS-B and hCS-L genes) (15). PGH binds to the $\mathrm{GH}$ receptors in maternal tissues $(3,16-19)$. Furthermore, PGH is the protein product of the GH-V gene and consists of 191 amino acid residues (20-23). It consists of glycosylated variants, hGH-V2, GH-V3 protein and various isoforms of PGH (24-29).

The presence of GH and PGH receptors in the syncytiotrophoblast indicates that this hormone contributes to the development and function of the placenta via an autocrine mechanism. Various studies have reported a significant decrease in maternal serum PGH concentrations in pregnancies complicated by fetal growth restriction (FGR) $(12,30)$, 
while increased maternal serum levels have been correlated with the presence of fetal chromosomal abnormalities (31-33).

\section{PGH in pregnancy and fetal growth}

The placenta delivers maternal blood (containing oxygen and nutrients) to the fetus, thus controlling its growth. Placental hormones, along with maternal pituitary gland hormones, interact and mediate the metabolic adaptations and changes during pregnancy (34-36); however, these hormones undergo changes throughout gestation.

Prolactin (PRL) produced by the pituitary gland of the mother and human chorionic somatomammotropin hormone [CSH; or human placental lactogen (hPL)], increase markedly in maternal circulation in normal pregnancy $(37,38)$. During early and mid-pregnancy, there is a sharp decrease in the expression levels of $\mathrm{GH}(\mathrm{GH} 1)$, and after the twenty-fourth week of gestation $\mathrm{GH} 1$ is no longer detected in the maternal serum (39). GH1 is replaced by GH2 or syncytiotrophoblast-produced PGH (39). There is a tonical secretion of the variant $\mathrm{GH}$, which increases from the twentieth week of gestation until term, reaching levels of 20-40 $\mathrm{ng} / \mathrm{ml}$ (39). PGH binds with high and low affinity to GH and to PRL receptors, respectively (39). Thus, during mid and late gestation, the mother exhibits high levels of PRL, peaking at $150-180 \mathrm{ng} / \mathrm{ml}$. The $\mathrm{hPL}$ production rate near term is $\sim \mathrm{g} /$ day, which is the greatest known of any human hormone, and PGH levels reach $14 \mathrm{ng} / \mathrm{ml}$ after 28 weeks. In addition, hPL and PRL are secreted directly into the fetal circulation, while PGH is detected primarily in the maternal blood (39-41).

Männik et al (42) assessed the association between the expression levels of PGH and CSH, and the birth weight in normal, healthy pregnancies at term using a fluorescent-labeled semiquantitative RT-PCR as well as gene-specific restriction analysis. The study was conducted in a homogeneous healthy sample of Caucasian pregnant women without any metabolic or pregnancy-associated pathological conditions. Women with gestational diabetes mellitus (DM) and toxemia, as well as fetuses affected by infections, and genetic and congenital disorders were excluded. The results of the study facilitated with elucidating the physiological and pathological role of PGH and CSH in the regulation of fetal growth. Despite the fact that half of the PGH transcripts encode proteins with $\mathrm{C}$ termini distinct from the major $\mathrm{GH} 2$ product (GH2-1), their function remains unclear. The GH2-1 expression was demonstrated to be lower in the placentas from pregnancies with small for gestational age (SGA) fetuses, while it was normal in pregnancies with large for gestational age (LGA) fetuses. It was demonstrated that the expression levels of the major CSH transcript (CSH1) were greater in the placentas of LGA babies, but remained unchanged in those of SGA babies. Previous studies by Caufriez et al (6), McIntyre et al (12) and Ursell et al (43), observed that decreased levels of PGH in pregnancies resulted in SGA neonates and high maternal serum levels of CSH in women with gestational diabetes $(6,12,43)$.

PGH is not regulated by placental GH-releasing hormone, but responds inversely to the levels of glucose and insulin in maternal circulation, assuring glucose disposal to the fetus, by increasing nutrient availability to the fetus either directly or indirectly via IGF-I $(9,44,45)$. A positive correlation between PGH and fetal and neonatal weight has been demonstrated (46-48). PGH levels decline during an oral glucose tolerance test in women with gestational diabetes (4). As the major glucose transporter (Glut 1) is expressed by syncytiotrophoblast cells and remains directly in contact with maternal blood, these cells adjust PGH secretion according to the maternal serum glucose level.

In the blood of pregnant women metabolic interdependence is observed between PGH and IGF-I. During pregnancy, the concentration of PGH and IGF-I increases proportionately and, following delivery, their concentration decreases. GH1 blockade appears to be released during labor and delivery, and its level increases three-fold, it then returns to normal postpartum (49). Pedersen et al (50) conducted a study to investigate whether maternal levels of PGH, IGF-I and hPL are associated with the growth rate of biparietal diameter during the first half of gestation. High maternal PGH concentrations were observed in fetuses with increased first-trimester growth rates in the unadjusted and adjusted analyses for a variety of known and potential confounders. It was concluded that PGH may contribute in the regulation of fetal growth from the first stages of the pregnancy (50).

PGH is considered to be key in the signaling pathways of maternal metabolic adaptation to pregnancy. This is a pregnancy-specific hormone that along with other hormones coordinates trophoblast invasion (8), fetal growth $(3,46,51)$ and maternal adaptation to pregnancy $(9,10)$. The somatotrophic, lactogenic and lipolytic action of PGH resembles that of pituitary GH. However, PGH secretion follows a non-pulsatile pattern (52), unlike the pulsatile mode of GH. PGH mRNA and protein are expressed in syncytiotrophoblast and EVCT $(20,35,53,54)$.

PGH is detectable in maternal blood as early as at 5 weeks of gestation (3). Its level increases throughout pregnancy until term (51), when it has been observed to either plateau $(5,6)$ or slightly decrease (55). The interaction between placental hormone expression and maternal nutritional status contributes to the regulation of fetal growth. The polymorphic or epigenetic regulation of PGH and CSH expression changes the secretion of other hormones or growth factors (insulin or IGF-I), and the circulation and disposal of maternal nutrients. Reduction in expression of PGH may reduce lipolysis and the levels of circulating IGF-I, as PGH is a potent insulin antagonist, as well as a lipolytic hormone that stimulates production of IGF-I during pregnancy $(6,11,56-58)$. This may reduce the availability of maternal nutrient and limit placental nutrient transfer; hence, may reduce fetal weight (59). By contrast, there are theories stating that increases in expression levels of $\mathrm{CSH}$ may promote insulin resistance, lipolysis and IGF-I expression in maternal tissues $(60,61)$. This may lead to increased maternal nutrient availability and placental transfer, which in turn results in promotion of fetal growth. However, these theories are controversial. Lipolysis reduction due to deficiency of PGH should be correlated with increased maternal fat levels; however, many pregnant women with SGA fetuses/neonates have low body mass index values (12).

CSH is lipolytic and IGF-I-tropic is weak (16). As CSH and PGH have almost the same molecular weight, it is possible that CSH is purified from human placenta in quantities that induce lipolysis in vivo and in vitro $(62,63)$. Alternatively, the PGH 
Table I. Association between PGH and pregnancy complications.

Author, year Condition Outcome Association Refs.

Hübener et al, 2015

GTD

hGH-V may be detected in all types of GTD by

Ringholm et al, T1DM 2015

Schock et al,

EOC 2015

Eleftheriades et al, GDM

2014

Higgins et al,

T1DM

2012

Sifakis et al, 2011

PE

Männik et al, SGA neonate 2010

Sifakis et al, Trisomies 2010

Christiansen et al, DS 2009 Papadopoulou et al, 2008

DS

Papadopoulou et al, IUGR associated 2006 with PE immunohistochemistry, as well as by serum analysis and may therefore serve as a novel biomarker for the disease

\section{Lower levels of placental growth hormone in early} pregnancy in women with T1DM and LGA infants Higher insulin-like growth factor -I levels in pregnancy may be associated with lower risk of invasive and endometrioid EOC

Strongly associated

Associated

Associated

At 11-14 weeks in pregnancies that develop GDM the maternal serum levels of PIGF were increased

Associated Maternal T1DM PGH correlated with antenatal fetal weight and birth weight suggesting a significant role for PGH in growth in diabetic pregnancy.

PE group serum PGH level during the first trimester was normal, indicating that it is unlikely that this hormone is involved in the pathogenesis of $\mathrm{PE}$ The expression profile of placenta $1 \mathrm{hGH} /$ chorionic somatomammotropin hormone genes in placenta is altered in pregnancies accompanied by SGA and LGA compared with appropriate for gestational age newborns

In the first trimester, maternal serum hPGH levels in trisomy 21 and trisomy 18 pregnancies are reduced PGH levels are early first trimester maternal serum markers for DS

The PGH levels in maternal serum were found to be higher at gestation weeks 16-23 in pregnancies affected by fetal DS

Maternal serum and amniotic fluid PGH levels at 16-22 weeks are higher in pregnancies that will be complicated by IUGR associated with PE
Significant Associated (102)

Not associated

Associated

Associated

Strongly Associated

Associated

Associated

PGH, placental growth hormone; GTD, gestational trophoblastic disease; T1DM, type 1 diabetes mellitus; EOC, epithelial ovarian cancer; GDM, gestational diabetes mellitus; PE, preeclampsia; SGA, small-for-gestational age; DS, Down syndrome; LGA, large for gestational age; IUGR, intrauterine growth retardation; PIGF, placental growth factor.

fall may be an indirect effect of maternal undernutrition. A decrease in pregnancy weight gain would augment the sensitivity of maternal insulin and plasma adiponectin, reducing the expression level of PGH in trophoblast cells in vitro (64). A decline in the expression levels of PGH may reduce maternal lipolysis, thereby somewhat recompensing the reduction of maternal fat stores. A combination of these mechanisms may result in reduction of PGH and maternal IGF-I in pregnancies associated with FGR.

The physiological role of $\mathrm{CSH}$ and $\mathrm{PGH}$ is controversial, as certain women with $\mathrm{CSH}$ and/or $\mathrm{PGH}$ gene deletions experienced a normal pregnancy outcome in terms of children birth weight (34). This may indicate that neither CSH nor PGH is required for normal fetal growth; however, it is possible that other hormones, such as pituitary GH or PRL may counterbalance PGH or CSH deficiency. Various studies on $\mathrm{GH}$-deficient mouse receptors $(63,65)$ provide evidence that somatogens and lactogens modify metabolism and fetal growth via overlapping, but distinct actions (34). There is no clear evidence regarding maternal serum $\mathrm{PGH}$ concentration during labor (66); however, abrupt decrease has been reported (30).

\section{PGH in pathological pregnancy}

PGH and GH binding protein are potentially early first trimester maternal serum markers for Down syndrome (33,67-70). Higher PGH levels in amniotic fluid were reported in fetuses with Down syndrome compared with healthy pregnancies during the second trimester (71). PGH was detected in all amniotic fluid samples, indicating that it could possibly enter the fetal 
compartment; until then it was proposed that PGH was present only in maternal circulation (71). Sifakis et al (72) investigated the maternal serum concentration of PGH in trisomy 18 and trisomy 21 pregnancies at 11 to 13 weeks of gestation, and examined the possible association between fetal nuchal translucency thickness and maternal serum free $\beta$-human chorionic gonadotrophin $(\beta-h \mathrm{CG})$ and pregnancy associated plasma proteinA (PAPPA). Serum PGH was reduced in trisomy 21 and trisomy 18 compared with euploid pregnancies in the first trimester. There was a significant association between serum hPGH and PAPPA in the euploid $(\mathrm{P}=0.006)$ and trisomy 21 pregnancies $(\mathrm{P}=0.030)$, although not in trisomy 18 pregnancies $(\mathrm{P}=0.445)(72)$. Alldred et al (73), in a review of first trimester serum screening tests for trisomy 21 , reported that the double test (comprising PAPP-A and free hCG in combination with maternal age) detects $\sim 70 \%$ of the affected pregnancies for a $5 \%$ false positive rate $(73)$.

There is differential regulation of the major placental syncytiotrophoblast protein members of the GH/CSH hormone family. Previous studies reported low maternal levels of PGH and $\mathrm{CSH}$ in pregnancy complications, such as hypertension, preeclampsia (PE) and intrauterine growth restriction (IUGR) (74-78). PGHs have an effect on placental trophoblast invasion and normal growth. Various studies have been conducted to investigate the correlation between maternal serum levels of PGH and IUGR $(6,12,30,79)$. The concentration of PGH has been identified to be lower in SGA, while there are conflicting results regarding $\mathrm{PGH}$ in $\mathrm{PE}(55,80-83)$. Numerous studies have reported lower PGH levels in pregnant women with clinically established PE, following 20-22 weeks of gestation (79,84-97).

PGH maternal and amniotic fluid concentrations were increased at 16-22 weeks of gestation in women that subsequently developed PE and IUGR (80). The same authors, Sifakis et al (2) conducted a study to investigate the maternal serum concentration of PGH at 11-13 weeks of gestation in pregnancies that subsequently developed PE, and examined the possible association with uterine artery pulsatility index (PI) and maternal serum PAPPA. The median serum PGH concentration was not observed to be significantly different in the pregnancies that subsequently developed PE when compared with that in the unaffected group, whereas uterine artery PI was increased and serum PAPPA was decreased. No significant association was identified between serum PGH and gestational age at delivery, uterine artery PI, or serum PAPPA PAPPA multiples of median (MoM) in the group that developed PE. The normal serum PGH level during the first trimester in the PE group indicates that it is unlikely that this hormone is involved in the underlying mechanisms or the pathogenesis of PE (2).

Mittal et al (55) conducted a cross sectional study to investigate the alterations of the maternal serum concentrations of PGH in women with PE, women with PE and an SGA neonate and women with SGA neonates alone. In patients with severe PE, the median serum PGH concentration was higher $(23,076 \mathrm{pg} / \mathrm{ml})$ compared with women with uncomplicated pregnancies $(12,157 \mathrm{pg} / \mathrm{ml})$, women with SGA neonates (SGA group, median $10,206 \mathrm{pg} / \mathrm{ml} ; \mathrm{P}<0.05)$, as well as women with $\mathrm{PE}$ and SGA (PE + SGA group,1,027 pg/ml; P<0.05). PE was correlated with increased median values of $\mathrm{PGH}$ in the maternal and fetal compartment when compared with normal pregnancies. Differences observed in the median maternal serum level of PGH among pregnant women with PE and SGA, SGA alone, and in healthy pregnancies were not statistically significant $(\mathrm{P}>0.05)$. The umbilical serum concentration of PGH (median value) was significantly higher in neonates of women with PE (356.1 vs. $128.5 \mathrm{pg} / \mathrm{ml}$ in normal pregnancies; $\mathrm{P}<0.01)$. Furthermore, $\mathrm{PGH}$ was detectable in all cord blood specimens. These observations indicate that PGH may be involved in the pathophysiology and the underlying mechanisms of PE and FGR.

The role of PGH and the IGF-axis in IUGR has been further investigated during a study conducted by Koutsaki et al (98) using in term placentas from 47 pregnancies complicated with IUGR. Decreased placental expression of PGH, IGF-I and IGF binding protein-I was observed. The authors concluded that further investigation is required to clarify whether these observations represent a causative factor of IUGR, or accompany other pathogenetic underlying mechanisms. However, Sifakis et al (99) demonstrated that, in early pregnancy (11-13 week of gestation), the concentrations of PGH in maternal serum is not altered in pregnancies that resulted in SGA neonates (99).

It remains unclear whether $\mathrm{PGH}$ is involved in the regulation of the growth of the fetus in pregnancies with pre-existing DM or in those complicated by gestational DM (GDM) $(100,101)$. There is a higher incidence of macrosomia in the babies of diabetic women; however, there are few studies that demonstrate high concentrations of serum maternal PGH in diabetic pregnancies. In a prospective study by Higgins et al (102) maternal PGH was significantly associated with fetal weight estimated by ultrasonography $(\mathrm{P}=0.02)$, birth weight $(\mathrm{P}=0.05)$ and birth weight centile $(\mathrm{P}=0.03)$ in pregnancies with type 1 DM (T1DM) (102). A study by Fuglsang et al (103) indicated a role of PGH in the regulation of IGFs and fetal growth in T1DM. However, an increase in insulin requirements in type 1 diabetic patients during pregnancy was not associated with the levels of PGH $(103,104)$. A more recent study by Ringholm et al (104) reported PGH at lower levels during early pregnancy in women with T1DM and large for gestational age (LGA) infants (104). GDM and pre-gestational diabetes pose risks to the mother and the fetus, and may associated with abnormal fetal growth. In human pregnancy, PGH appears to contribute to the mechanisms of regulation of maternal insulin resistance and may exert an influence on fetal growth by modifying nutrient availability and via paracrine activities in the developing placenta. Thus, the evidence of a clear pathophysiological role of $\mathrm{PGH}$ in the development of fetal macrosomia attributed to hyperglycaemia is insufficient; however, in vitro studies indicate a potential feto-placental feedback as a modulator of fetal growth (105).

\section{PGH in oncogenesis and in gestational trophoblastic disease}

It has been demonstrated that signaling of IGF-I may promote the development of ovarian tumors by exerting proangiogenic, mitotic and antiapoptotic effects (106). Production of maternal IGF-I is regulated by PGH during pregnancy. To the best of our knowledge, there are no existing studies evaluating the 
role of PGH and IGF-I in pregnancy and epithelial ovarian cancer (EOC). A study by Schock et al (106) provides data on PGH and IGF-I levels in pregnancy and EOC risk. A total of 1,045 EOC cases were investigated. Placental GH and IGF-I levels were analyzed in maternal serum from the last pregnancy before EOC diagnosis and served as a control. Higher levels of IGF-I were associated with a decrease in the risk for invasive [odds ratio (OR), 0.79 (0.62-1.02)] and endometrioid [OR, 0.55 (0.28-1.07)] tumors; however, these observations were not statistically significant. This protective association was stronger between higher IGF-I levels and the risk of invasive EOC in women aged $<55$ years at diagnosis [OR 0.74 (0.57-0.96)]. These data suggest that higher IGF-I levels during pregnancy may be associated with a decreased risk of invasive and endometrioid EOC.

Gestational trophoblastic disease (GTD) arising from the placental villous trophoblast is associated with abnormal placental trophoblast proliferation. PGH is significant in the regulation of placental growth and development, and exerts various angiogenic actions. Furthermore, hGHV is detected in the different types of GTD by immunohistochemistry and serum measurements. The value of PGH as a potential biomarker for GTD has been investigated (107); however, the available data from the literature are limited.

\section{Conclusion}

PGH performs an important role in the regulation of placental growth and development, as well as in fetal growth by increasing nutrient availability, either directly or indirectly, via IGF-I. As with many other hormones, PGH may be used as a biomarker for a variety of abnormal pregnancy conditions and complications. However, further investigation is required to clarify the value, if any, of PGH as a clinically useful biomarker for particular pregnancy-associated pathological conditions. It is possible that the measured levels of PGH in maternal circulation may correspond to the synthesis rate of PGH; however, larger studies simultaneously evaluating placental expression and maternal and/or fetal serum concentration are required. In addition, important aspects of the physiological actions of PGH require further clarification. The same is true for the association between PGH and the IGF-axis, and other hormones of placental or maternal origin. The majority of previous studies thus far focused upon investigating the alterations of $\mathrm{PGH}$ in PE, FGR, GDM, as well as the more common aneuploidies. Despite the controversial results, it has been demonstrated that evaluation of the maternal concentrations throughout pregnancy may offer ground for further investigation and establishment of a clinically useful role of PGH. Details of the underlying mechanisms of the regulation of $\mathrm{PGH}$ remain unknown or poorly understood, although it has been shown that PGH has an important role in placental development, fetal growth and the outcome of the pregnancy.

\section{References}

1. Fuglsang $\mathrm{J}$ and Ovesen P: Aspects of placental growth hormone physiology. Growth Horm IGF Res 16: 67-85, 2006.

2. Sifakis S, Akolekar R, Mantas N, Kappou D and Nicolaides KH: Maternal serum human placental growth hormone (hPGH) at 11 to 13 weeks of gestation in preeclampsia. Hypertens Pregnancy 30: 74-82, 2011.
3. Chellakooty M,Vangsgaard K,Larsen T, Scheike T,Falck-Larsen J, Legarth J, Andersson AM, Main KM, Skakkebaek NE and Juul A: A longitudinal study of intrauterine growth and the placental growth hormone $(\mathrm{GH})$-insulin-like growth factor I axis in maternal circulation: Association between placental GH and fetal growth. J Clin Endocrinol Metab 89: 384-391, 2004.

4. Alsat E, Guibourdenche J, Luton D, Frankenne F and Evain-Brion D: Human placental growth hormone. Am J Obstet Gynecol 177: 1526-1534, 1997.

5. Caufriez A, Frankenne F, Englert Y, Golstein J, Cantraine F, Hennen G and Copinschi G: Placental growth hormone as a potential regulator of maternal IGF-I during human pregnancy. Am J Physiol 258: E1014-E1019, 1990.

6. Caufriez A, Frankenne F, Hennen G and Copinschi G: Regulation of maternal IGF-I by placental GH in normal and abnormal human pregnancies. Am J Physiol 265: E572-E577, 1993.

7. Vatten LJ, Nilsen TI, Juul A, Jeansson S, Jenum PA and Eskild A: Changes in circulating level of IGF-I and IGF-binding protein-1 from the first to second trimester as predictors of preeclampsia. Eur J Endocrinol 158: 101-105, 2008.

8. Lacroix MC, Guibourdenche J, Fournier T, Laurendeau I, Igout A, Goffin V, Pantel J, Tsatsaris V and Evain-Brion D: Stimulation of human trophoblast invasion by placental growth hormone. Endocrinology 146: 2434-2444, 2005.

9. Lacroix MC, Bolifraud P, Durieux D, Pauloin A, Vidaud M and Kann G: Placental growth hormone and lactogen production by perifused ovine placental explants: Regulation by growth hormone-releasing hormone and glucose. Biol Reprod 66: $555-561,2002$.

10. Takata K, Kasahara T, Kasahara M, Ezaki O and Hirano H: Localization of erythrocyte/HepG2-type glucose transporter (GLUT1) in human placental villi. Cell Tissue Res 267: 407-412, 1992.

11. Barbour LA, Shao J, Qiao L, Pulawa LK, Jensen DR, Bartke A, Garrity M, Draznin B and Friedman JE: Human placental growth hormone causes severe insulin resistance in transgenic mice. Am J Obstet Gynecol 186: 512-517, 2002.

12. McIntyre HD, Serek R, Crane DI, Veveris-Lowe T, Parry A, Johnson S, Leung KC, Ho KK, Bougoussa M, Hennen G, et al: Placental growth hormone (GH), GH-binding protein, and insulin-like growth factor axis in normal, growth-retarded, and diabetic pregnancies: Correlations with fetal growth. J Clin Endocrinol Metab 85: 1143-1150, 2000.

13. Frankenne F, Alsat E, Scippo ML, Igout A, Hennen G and Evain-Brion D: Evidence for the expression of growth hormone receptors in human placenta. Biochem Biophys Res Commun 182: 481-486, 1992.

14. Harper ME, Barrera-Saldaña HA and Saunders GF: Chromosomal localization of the human placental lactogen-growth hormone gene cluster to 17q22-24. Am J Hum Genet 34: 227-234, 1982.

15. Handwerger $S$ and Freemark M: The roles of placental growth hormone and placental lactogen in the regulation of human fetal growth and development. J Pediatr Endocrinol Metab 13: $343-356,2000$.

16. Freemark M, Fleenor D, Driscoll P, Binart N and Kelly P: Body weight and fat deposition in prolactin receptor-deficient mice. Endocrinology 142: 532-537, 2001.

17. George DL, Phillips JA III, Francke U and Seeburg PH: The genes for growth hormone and chorionic somatomammotropin are on the long arm of human chromosome 17 in region q21 to qter. Hum Genet 57: 138-141, 1981.

18. Struman I, Bentzien F, Lee H, Mainfroid V, D'Angelo G, Goffin V, Weiner RI and Martial JA: Opposing actions of intact and N-terminal fragments of the human prolactin/growth hormone family members on angiogenesis: An efficient mechanism for the regulation of angiogenesis. Proc Natl Acad Sci USA 96: 1246-1251, 1999

19. Nachtigal MW, Nickel BE and Cattini PA: Pituitary-specific repression of placental members of the human growth hormone gene family. A possible mechanism for locus regulation. J Biol Chem 268: 8473-8479, 1993.

20. Lacroix MC, Guibourdenche J, Frendo JL, Muller F and Evain-Brion D: Human placental growth hormone - a review. Placenta 23 (Suppl A): S87-S94, 2002.

21. Silva CM, Kloth MT, Lyons CE, Dunn CR and Kirk SE: Intracellular signaling by growth hormone variant $(\mathrm{GH}-\mathrm{V})$. Growth Horm IGF Res 12: 374-380, 2002.

22. Cacciari E, Pirazzoli P, Gualandi S, Baroncini C, Baldazzi L, Trevisani B, Capelli M,Zucchini S, Balsamo A, Cicognani A, et al: Molecular study of human growth hormone gene cluster in three families with isolated growth hormone deficiency and similar phenotype. Eur J Pediatr 153: 635-641, 1994. 
23. Mullis PE, Akinci A, Kanaka C, Eblé A and Brook CG: Prevalence of human growth hormone-1 gene deletions among patients with isolated growth hormone deficiency from different populations. Pediatr Res 31: 532-534, 1992.

24. Frankenne F, Closset J, Gomez F, Scippo ML, Smal J and Hennen G: The physiology of growth hormones (GHs) in pregnant women and partial characterization of the placental $\mathrm{GH}$ variant. J Clin Endocrinol Metab 66: 1171-1180, 1988.

25. Frankenne F, Scippo ML, Van Beeumen J, Igout A and Hennen G: Identification of placental human growth hormone as the growth hormone-V gene expression product. J Clin Endocrinol Metab 71: 15-18, 1990.

26. Nickel BE, Kardami E and Cattini PA: The human placental growth hormone variant is mitogenic for rat lymphoma Nb2 cells. Endocrinology 126: 971-976, 1990.

27. Cooke NE, Ray J, Emery JG and Liebhaber SA: Two distinct species of human growth hormone-variant mRNA in the human placenta predict the expression of novel growth hormone proteins. J Biol Chem 263: 9001-9006, 1988.

28. Selden RF, Wagner TE, Blethen S, Yun JS, Rowe ME and Goodman HM: Expression of the human growth hormone variant gene in cultured fibroblasts and transgenic mice. Proc Natl Acad Sci USA 85: 8241-8245, 1988.

29. Ghizzoni L, Duquesnoy P, Torresani T, Vottero A, Goossens M and Bernasconi S: Isolated growth hormone deficiency type IA associated with a 45-kilobase gene deletion within the human growth hormone gene cluster in an Italian family. Pediatr Res 36: 654-659, 1994

30. Mirlesse V, Frankenne F, Alsat E, Poncelet M, Hennen G and Evain-Brion D: Placental growth hormone levels in normal pregnancy and in pregnancies with intrauterine growth retardation. Pediatr Res 34: 439-442, 1993

31. Moghadam S, Engel W, Bougoussa M, Hennen G, Igout A and Sancken U: Maternal serum placental growth hormone and insulinlike growth factor binding proteins 1 and 3 in pregnancies affected by fetal aneuploidy and other abnormalities: Implications for prenatal diagnosis of trisomy 21. Fetal Diagn Ther 13: 291-297, 1998.

32. Curran AJ, Peacey SR and Shalet SM: Is maternal growth hormone essential for a normal pregnancy? Eur J Endocrinol 139: 54-58, 1998

33. Papadopoulou E, Sifakis S, Giahnakis E, Fragouli Y, Karkavitsas N, Koumantakis E and Kalmanti M: Human placental growth hormone is increased in maternal serum in pregnancies affected by Down syndrome. Fetal Diagn Ther 23 : 211-216, 2008

34. Freemark M: Regulation of maternal metabolism by pituitary and placental hormones: Roles in fetal development and metabolic programming. Horm Res 65 (Suppl 3): 41-49, 2006.

35. Ray J, Okamura H, Kelly PA, Cooke NE and Liebhaber SA: Human grow th hormone-variant demonstrates a receptor binding profile distinct from that of normal pituitary growth hormone. J Biol Chem 265: 7939-7944, 1990.

36. Gootwine E: Placental hormones and fetal-placental development. Anim Reprod Sci 82-83: 551-566, 2004.

37. Schock H, Zeleniuch-Jacquotte A, Lundin E, Grankvist K, Lakso HA, Idahl A, Lehtinen M, Surcel HM and Fortner RT: Hormone concentrations throughout uncomplicated pregnancies: A longitudinal study. BMC Pregnancy Childbirth 16: 146, 2016.

38. Walker WH, Fitzpatrick SL, Barrera-Saldaña HA, Resendez-Perez D and Saunders GF: The human placental lactogen genes: Structure, function, evolution and transcriptional regulation. Endocr Rev 12: 316-328, 1991.

39. Freemark M: Placental hormones and the control of fetal growth J Clin Endocrinol Metab 95: 2054-2057, 2010.

40. MacLeod JN, Worsley I, Ray J, Friesen HG, Liebhaber SA and Cooke NE: Human growth hormone-variant is a biologically active somatogen and lactogen. Endocrinology 128: 1298-1302, 1991.

41. Wu Z, Bidlingmaier M, Friess SC, Kirk SE, Buchinger P, Schiessl B and Strasburger CJ: A new nonisotopic, highly sensitive assay for the measurement of human placental growth hormone: Development and clinical implications. J Clin Endocrinol Metab 88: 804-811, 2003.

42. Männik J, Vaas P, Rull K, Teesalu P, Rebane T and Laan M: Differential expression profile of growth hormone/chorionic somatomammotropin genes in placenta of small- and large-for-gestational-age newborns. J Clin Endocrinol Metab 95: 2433-2442, 2010.

43. Ursell W, Brudenell $\mathrm{M}$ and Chard T: Placental lactogen levels in diabetic pregnancy. BMJ 2: 80-82, 1973.
44. Langford KS, Nicolaides KH, Jones J, Abbas A, McGregor AM and Miell JP: Serum insulin-like growth factor-binding protein-3 (IGFBP-3) levels and IGFBP-3 protease activity in normal, abnormal, and multiple human pregnancy. J Clin Endocrinol Metab 80: 21-27, 1995.

45. Reece EA, Wiznitzer A, Le E, Homko CJ, Behrman H and Spencer EM: The relation between human fetal growth and fetal blood levels of insulin-like growth factors I and II, their binding proteins, and receptors. Obstet Gynecol 84: 88-95, 1994.

46. Coutant R, Boux de Casson F, Douay O, Mathieu E, Rouleau S, Beringue F, Gillard P, Limal JM and Descamps P: Relationships between placental GH concentration and maternal smoking, newborn gender, and maternal leptin: Possible implications for birth weight. J Clin Endocrinol Metab 86: 4854-4859, 2001

47. Boutsikou T, Malamitsi-Puchner A, Economou E, Boutsikou M, Puchner KP and Hassiakos D: Soluble vascular endothelial growth factor receptor-1 in intrauterine growth restricted fetuses and neonates. Early Hum Dev 82: 235-239, 2006.

48. Malamitsi-Puchner A, Boutsikou T, Economou E, Sarandakou A, Makrakis E, Hassiakos D, et al: Vascular endothelial growth factor and placenta growth factor in intrauterine growth-restricted fetuses and neonates. Mediat Inflamm 2005: 293-297, 2005.

49. Kedzia A, Tarka A, Petriczko E, Pruski D and Iwaniec K: Placental growth hormone (PGH), pituitary growth hormone (GH1), insulin-like growth factor (IGF-I) and ghrelin in pregnant women's blood serum. Ginekol Pol 84: 620-623, 2013.

50. Pedersen NG, Juul A, Christiansen M, Wøjdemann KR and Tabor A: Maternal serum placental growth hormone, but not human placental lactogen or insulin growth factor-1, is positively associated with fetal growth in the first half of pregnancy. Ultrasound Obstet Gynecol 36: 534-541, 2010.

51. Chellakooty M, Skibsted L, Skouby SO, Andersson AM, Petersen JH, Main KM, Skakkebaek NE and Juul A: Longitudinal study of serum placental $\mathrm{GH}$ in 455 normal pregnancies: Correlation to gestational age, fetal gender, and weight. J Clin Endocrinol Metab 87: 2734-2739, 2002.

52. Eriksson L, Frankenne F, Edèn S, Hennen G and Von Schoultz B: Growth hormone 24-h serum profiles during pregnancy- -lack of pulsatility for the secretion of the placental variant. Br J Obstet Gynaecol 96: 949-953, 1989.

53. Liebhaber SA, Urbanek M, Ray J, Tuan RS and Cooke NE: Characterization and histologic localization of human growth hormone-variant gene expression in the placenta. J Clin Invest 83: 1985-1991, 1989

54. Scippo ML, Frankenne F, Hooghe-Peters EL, Igout A, Velkeniers B and Hennen G: Syncytiotrophoblastic localization of the human growth hormone variant mRNA in the placenta. Mol Cell Endocrinol 92: R7-R13, 1993.

55. Mittal P, Espinoza J, Hassan S, Kusanovic JP, Edwin SS, Nien JK, Gotsch F, Than NG, Erez O, Mazaki-Tovi S, et al: Placental growth hormone is increased in the maternal and fetal serum of patients with preeclampsia. J Matern Fetal Neonatal Med 20: 651-659, 2007.

56. Goodman HM, Tai LR, Ray J, Cooke NE and Liebhaber SA: Human growth hormone variant produces insulin-like and lipolytic responses in rat adipose tissue. Endocrinology 129: 1779-1783, 1991.

57. Street ME, Seghini P, Fieni S, Ziveri MA, Volta C, Martorana D, Viani I, Gramellini D and Bernasconi S: Changes in interleukin- 6 and IGF system and their relationships in placenta and cord blood in newborns with fetal growth restriction compared with controls. Eur J Endocrinol 155: 567-574, 2006.

58. Street ME, Seghini P, Ziveri MA, Fieni S, Volta C, Neri TM, Viani I, Bacchi-Modena A and Bernasconi S: Interleukin-6 and insulin-like growth factor system relationships and differences in the human placenta and fetus from the 35 th week of gestation. Growth Horm IGF Res 16: 365-372, 2006.

59. Fowden AL and Forhead AJ: Endocrine regulation of feto-placental growth. Horm Res 72: 257-265, 2009.

60. Handwerger S: The growth hormone gene cluster: Physiological actions and regulation during pregnancy. Growth Genet Horm 25: $1-8,2009$

61. Rechler MM and Clemmons DR: Regulatory Actions of Insulin-like Growth Factor-binding Proteins. Trends Endocrinol Metab 9: 176-183, 1998

62. Freemark M, Avril I, Fleenor D, Driscoll P, Petro A, Opara E, Kendall W, Oden J, Bridges S, Binart N, et al: Targeted deletion of the PRL receptor: Effects on islet development, insulin production, and glucose tolerance. Endocrinology 143: 1378-1385, 2002. 
63. Fleenor D, Oden J, Kelly PA, Mohan S, Alliouachene S, Pende M, Wentz S, Kerr J and Freemark M: Roles of the lactogens and somatogens in perinatal and postnatal metabolism and growth: Studies of a novel mouse model combining lactogen resistance and growth hormone deficiency. Endocrinology 146: 103-112, 2005 .

64. McDonald EA and Wolfe MW: Adiponectin attenuation of endocrine function within human term trophoblast cells Endocrinology 150: 4358-4365, 2009.

65. Arumugam R, Fleenor D and Freemark M: Effects of lactogen resistance and GH deficiency on mouse metabolism: Pancreatic hormones, adipocytokines, and expression of adiponectin and insulin receptors. Endocrine 32: 182-191, 2007.

66. Wallner W, Sengenberger R, Strick R, Strissel PL, Meurer B, Beckmann MW and Schlembach D: Angiogenic growth factors in maternal and fetal serum in pregnancies complicated by intrauterine growth restriction. Clin Sci (Lond) 112: 51-57, 2007.

67. Christiansen M: Placental growth hormone and growth hormone binding protein are first trimester maternal serum markers of Down syndrome. Prenat Diagn 29: 1249-1255, 2009

68. Fisker S, Ebdrup L and Orskov H: Influence of growth hormone binding protein on growth hormone estimation in different immunoassays. Scand J Clin Lab Invest 58: 373-381, 1998.

69. Baviera G, Carbone C, Corrado F and Mastrantonio P: Placental growth hormone in Down's syndrome screening. J Matern Fetal Neonatal Med 16: 241-243, 2004.

70. Leung TY, Chan LW, Leung TN, Fung TY, Sahota DS and Lau TK: First-trimester maternal serum levels of placental hormones are independent predictors of second-trimester fetal growth parameters. Ultrasound Obstet Gynecol 27: 156-161, 2006

71. Sifakis S, Papadopoulou E, Konstantinidou A, Giahnakis E, Fragouli Y, Karkavitsas N, Koumantakis E and Kalmanti M: Increased levels of human placental growth hormone in the amniotic fluid of pregnancies affected by Down syndrome. Growth Horm IGF Res 19: 121-125, 2009.

72. Sifakis S, Akolekar R, Syngelaki A, De Cruz J and Nicolaides KH: Maternal serum human placental growth hormone at 11 to 13 weeks in trisomy 21 and trisomy 18 pregnancies. Prenat Diagn 30: 212-215, 2010

73. Alldred SK, Takwoingi Y, Guo B, Pennant M, Deeks JJ, Neilson JP and Alfirevic Z: First trimester serum tests for Down's syndrome screening. Cochrane Database Syst Rev 11: CD011975, 2015.

74. Verhaeghe J: Does the physiological acromegaly of pregnancy benefit the fetus? Gynecol Obstet Invest 66: 217-226, 2008.

75. Chaiworapongsa T, Romero R, Espinoza J, Bujold E, Mee Kim Y, Goncalves LF, Gomez R and Edwin S: Evidence supporting a role for blockade of the vascular endothelial growth factor system in the pathophysiology of preeclampsia. Young Investigator Award Am J Obstet Gynecol 190: 1541-1547, discussion 1547-1550, 2004.

76. Koga K, Osuga Y, Yoshino O, Hirota Y, Ruimeng X, Hirata T, Takeda S, Yano T, Tsutsumi $O$ and Taketani Y: Elevated serum soluble vascular endothelial growth factor receptor 1 (sVEGFR-1) levels in women with preeclampsia. J Clin Endocrinol Metab 88: 2348-2351, 2003.

77. Maynard SE, Min JY, Merchan J, Lim KH, Li J, Mondal S, Libermann TA, Morgan JP, Sellke FW, Stillman IE, et al: Excess placental soluble fms-like tyrosine kinase 1 (sFlt1) may contribute to endothelial dysfunction, hypertension, and proteinuria in preeclampsia. J Clin Invest 111: 649-658, 2003.

78. McKeeman GC, Ardill JE, Caldwell CM, Hunter AJ and McClure N: Soluble vascular endothelial growth factor receptor-1 (sFlt-1) is increased throughout gestation in patients who have preeclampsia develop. Am J Obstet Gynecol 191: 1240-1246, 2004

79. Evain-Brion D: Hormonal regulation of fetal growth. Horm Res 42: 207-214, 1994.

80. Papadopoulou E, Sifakis S, Giahnakis E, Fragouli Y, Karkavitsas N, Koumantakis E and Kalmanti M: Increased human placental growth hormone at midtrimester pregnancies may be an index of intrauterine growth retardation related to preeclampsia. Growth Horm IGF Res 16: 290-296, 2006.

81. Chaiworapongsa T, Romero R, Kim YM, Kim GJ, Kim MR, Espinoza J, Bujold E, Gonçalves L, Gomez R, Edwin S, et al Plasma soluble vascular endothelial growth factor receptor-1 concentration is elevated prior to the clinical diagnosis of pre-eclampsia. J Matern Fetal Neonatal Med 17: 3-18, 2005.

82. Crispi F, Domínguez C, Llurba E, Martín-Gallán P, Cabero L and Gratacós E: Placental angiogenic growth factors and uterine artery Doppler findings for characterization of different subsets in preeclampsia and in isolated intrauterine growth restriction. Am J Obstet Gynecol 195: 201-207, 2006.
83. Rajakumar A, Michael HM, Rajakumar PA, Shibata E, Hubel CA, Karumanchi SA, Thadhani R, Wolf M, Harger G and Markovic N: Extra-placental expression of vascular endothelial growth factor receptor-1, (Flt-1) and soluble Flt-1 (sFlt-1), by peripheral blood mononuclear cells (PBMCs) in normotensive and preeclamptic pregnant women. Placenta 26: 563-573, 2005.

84. Evain-Brion D, Alsat E, Igout A, Frankenne F and Hennen G: Placental growth hormone variant: Assay and clinical aspects. Acta Paediatr Suppl 399 (s399): 49-51, discussion 52, 1994.

85. Kupferminc MJ, Daniel Y, Englender T, Baram A, Many A, Jaffa AJ, Gull I and Lessing JB: Vascular endothelial growth factor is increased in patients with preeclampsia. Am J Reprod Immunol 38: 302-306, 1997.

86. Krauss T, Pauer HU and Augustin HG: Prospective analysis of placenta growth factor (PlGF) concentrations in the plasma of women with normal pregnancy and pregnancies complicated by preeclampsia. Hypertens Pregnancy 23: 101-111, 2004.

87. Levine RJ and Karumanchi SA: Circulating angiogenic factors in preeclampsia. Clin Obstet Gynecol 48: 372-386, 2005.

88. Levine RJ, Lam C, Qian C, Yu KF, Maynard SE, Sachs BP Sibai BM, Epstein FH, Romero R, Thadhani R, et al; CPEP Study Group: Soluble endoglin and other circulating antiangiogenic factors in preeclampsia. N Engl J Med 355: 992-1005, 2006.

89. Levine RJ, Maynard SE, Qian C, Lim KH, England LJ, Yu KF, Schisterman EF, Thadhani R, Sachs BP, Epstein FH, et al: Circulating angiogenic factors and the risk of preeclampsia. $\mathrm{N}$ Engl J Med 350: 672-683, 2004.

90. Levine RJ, Thadhani R, Qian C, Lam C, Lim KH, Yu KF, Blink AL, Sachs BP, Epstein FH, Sibai BM, et al: Urinary placental growth factor and risk of preeclampsia. JAMA 293: $77-85,2005$.

91. Lyall F, Greer IA, Boswell F and Fleming R: Suppression of serum vascular endothelial growth factor immunoreactivity in normal pregnancy and in pre-eclampsia. Br J Obstet Gynaecol 104: 223-228, 1997.

92. Robinson CJ, Johnson DD, Chang EY, Armstrong DM and Wang W: Evaluation of placenta growth factor and soluble Fms-like tyrosine kinase 1 receptor levels in mild and severe preeclampsia. Am J Obstet Gynecol 195: 255-259, 2006.

93. Staff AC, Braekke K, Harsem NK, Lyberg T and Holthe MR: Circulating concentrations of sFlt1 (soluble fms-like tyrosine kinase 1) in fetal and maternal serum during pre-eclampsia. Eur J Obstet Gynecol Reprod Biol 122: 33-39, 2005

94. Thadhani R, Mutter WP, Wolf M, Levine RJ, Taylor RN, Sukhatme VP, Ecker J and Karumanchi SA: First trimester placental growth factor and soluble fms-like tyrosine kinase 1 and risk for preeclampsia. J Clin Endocrinol Metab 89: 770-775, 2004

95. Torry DS, Wang HS, Wang TH, Caudle MR and Torry RJ: Preeclampsia is associated with reduced serum levels of placenta growth factor. Am J Obstet Gynecol 179: 1539-1544, 1998.

96. Venkatesha S, Toporsian M, Lam C, Hanai J, Mammoto T, Kim YM, Bdolah Y, Lim KH, Yuan HT, Libermann TA, et al: Soluble endoglin contributes to the pathogenesis of preeclampsia. Nat Med 12: 642-649, 2006

97. Zhou Y, McMaster M, Woo K, Janatpour M, Perry J, Karpanen T, Alitalo K, Damsky C and Fisher SJ: Vascular endothelial growth factor ligands and receptors that regulate human cytotrophoblast survival are dysregulated in severe preeclampsia and hemolysis, elevated liver enzymes, and low platelets syndrome. Am J Pathol 60: 1405-1423, 2002.

98. Koutsaki M, Sifakis S, Zaravinos A, Koutroulakis D Koukoura $\mathrm{O}$ and Spandidos DA: Decreased placental expression of hPGH, IGF-I and IGFBP-1 in pregnancies complicated by fetal growth restriction. Growth Horm IGF Res 21: 31-36, 2011.

99. Sifakis S, Akolekar R, Kappou D, Mantas N and Nicolaides KH: Maternal serum placental growth hormone at 11-13 weeks' gestation in pregnancies delivering small for gestational age neonates. J Matern Fetal Neonatal Med 25: 1796-1799, 2012

100. Hu L, Lytras A, Bock ME, Yuen CK, Dodd JG and Cattini PA: Detection of placental growth hormone variant and chorionic somatomammotropin-L RNA expression in normal and diabetic pregnancy by reverse transcriptase-polymerase chain reaction. Mol Cell Endocrinol 157: 131-142, 1999.

101. Eleftheriades M, Papastefanou I, Lambrinoudaki I, Kappou D, Lavranos D, Akalestos A, Souka AP, Pervanidou P, Hassiakos D and Chrousos GP: Elevated placental growth factor concentrations at 11-14 weeks of gestation to predict gestational diabetes mellitus. Metabolism 63: 1419-1425, 2014 
102. Higgins MF, Russell NE, Crossey PA, Nyhan KC, Brazil DP and McAuliffe FM: Maternal and fetal placental growth hormone and IGF axis in type 1 diabetic pregnancy. PLoS One 7: e29164, 2012.

103. Fuglsang J, Lauszus F, Flyvbjerg A and Ovesen P: Human placental growth hormone, insulin-like growth factor I and -II, and insulin requirements during pregnancy in type 1 diabetes. J Clin Endocrinol Metab 88: 4355-4361, 2003.

104. Ringholm L, Juul A, Pedersen-Bjergaard U, Thorsteinsson B Damm P and Mathiesen ER: Lower levels of placental growth hormone in early pregnancy in women with type 1 diabetes and large for gestational age infants. Growth Horm IGF Res 25: $312-315,2015$
105. McIntyre HD, Zeck W and Russell A: Placental growth hormone, fetal growth and the IGF axis in normal and diabetic pregnancy. Curr Diabetes Rev 5: 185-189, 2009.

106. Schock H, Fortner RT, Surcel HM, Grankvist K, Pukkala E, Lehtinen M and Lundin E: Early pregnancy IGF-I and placental GH and risk of epithelial ovarian cancer: A nested case-control study. Int J Cancer 137: 439-447, 2015.

107.Hübener C, Bidlingmaier M, Wu Z, Diebold J, Delius M, Friese K, Strasburger CJ and Hasbargen U: Human placental growth hormone: A potential new biomarker in gestational trophoblastic disease. Gynecol Oncol 136: 264-268, 2015. 